\title{
Treatment with a proton pump inhibitor improves glycaemic control in Psammomys obesus, a model of type 2 diabetes
}

\author{
T. B. Bödvarsdóttir • K. D. Hove • C. F. Gotfredsen • \\ L. Pridal • A. Vaag • A. E. Karlsen • J. S. Petersen
}

Received: 6 April 2010 / Accepted: 19 May 2010 /Published online: 30 June 2010

(C) The Author(s) 2010. This article is published with open access at Springerlink.com

\begin{abstract}
Aims/hypothesis Gastrin has been implicated in islet growth/neogenesis, and proton pump inhibitors (PPIs) have been shown to increase endogenous gastrin levels in animals and humans. Therefore, we investigated the effect of PPIs in a model of type 2 diabetes, Psammomys obesus. Methods P. obesus (morning blood glucose [mBG] 16.9 \pm $0.6 \mathrm{mmol} / \mathrm{l})$ were treated with vehicle or different doses $(1-$ $15 \mathrm{mg} / \mathrm{kg}$ ) of lansoprazole for 17 days.

Results Treatment with lansoprazole resulted in up to ninefold dose-dependent increases in endogenous gastrin levels $(p<0.05$ for $10 \mathrm{mg} / \mathrm{kg}$ lansoprazole vs vehicle). There was a significant reduction in $\mathrm{mBG}$ levels in all animals in the high-dose lansoprazole groups during the 17 day treatment period, whereas there was no significant improvement in $\mathrm{mBG}$ in animals in the vehicle groups. The $\mathrm{mBG}$ at end of study was $18.2 \pm 2.1,8.7 \pm 2.2(p<0.01)$, and $6.1 \pm 2.3(p<0.001) \mathrm{mmol} / \mathrm{l}$ for vehicle and lansoprazole 10 and $15 \mathrm{mg} / \mathrm{kg}$, respectively. The animals treated with $15 \mathrm{mg} / \mathrm{kg}$ lansoprazole, compared with vehicle, had a 2.3fold increase in the intensity of insulin staining in beta cells $(p=0.0002)$ and $50 \%$ higher beta cell mass $(p=0.04)$.
\end{abstract}

T. B. Bödvarsdóttir $(\bowtie) \cdot$ C. F. Gotfredsen · L. Pridal •

J. S. Petersen

Novo Nordisk A/S,

Novo Nordisk Park,

2760 Måløv, Denmark

e-mail: tora@novonordisk.com

K. D. Hove $\cdot$ A. Vaag

Steno Diabetes Centre,

Gentofte, Denmark

A. E. Karlsen

Hagedorn Research Institute,

Gentofte, Denmark
Conclusions/interpretations The PPI lansoprazole had significant glucose-lowering effects in an animal model of type 2 diabetes, an effect that is most likely mediated through an increase in endogenous gastrin levels.

Keywords Animal model · Beta cell mass · Gastrin ·

Glycaemic control Proton pump inhibitor.

Type 2 diabetes

Abbreviations
$\begin{array}{ll}\text { BCM } & \text { Beta cell mass } \\ \text { BW } & \text { Body weight } \\ \text { mBG } & \text { Morning blood glucose } \\ \text { PPI } & \text { Proton pump inhibitor } \\ \text { SPA } & \text { Scintillation proximity assay }\end{array}$

\section{Introduction}

The consistent finding of reduced functional pancreatic beta cell mass (BCM) not only in type 1 diabetes but also in type 2 diabetes has increased the focus on finding new treatments that may increase and/or cause regeneration of functional BCM. Gastrin has been shown to increase proliferation of human and rodent duct-like pancreatic cells in culture, and administration of gastrin stimulates beta cell neogenesis and expansion of the BCM in rodents [1,2]. During treatment with proton pump inhibitors (PPIs), endogenous gastrin levels are increased in humans and rodents, and in a recent publication Suarez-Pinzon et al. showed that PPI treatment of mice in a model of type 1 diabetes resulted in an almost threefold increase in endogenous gastrin levels and improvement in glycaemia [3].

Since no data have been published on the effect of gastrin or PPIs in type 2 diabetes, we decided to investigate 
whether treatment with the PPI lansoprazole would have beneficial effects on glycaemic control in a type 2 diabetes animal model, the gerbil Psammomys obesus. When this gerbil is fed a high-energy diet, morning blood glucose (mBG) levels are distinctly increased, with subsequent/ concomitant loss of beta cell function and mass [4].

\section{Methods}

Animals Male and female P. obesus (Harlan, Jerusalem, Israel) were fed low-energy $(10 \mathrm{~kJ} / \mathrm{g})$ chow until the age of 14-15 weeks, after which they were transferred to an ad libitum high-energy $(13 \mathrm{~kJ} / \mathrm{g})$ diet during which body weight (BW), mBG and $\mathrm{HbA}_{1 \mathrm{c}}$ were monitored for 4 weeks. The animals that showed increased $\mathrm{mBG}$ levels, defined as $\mathrm{mBG}>10 \mathrm{mmol} / \mathrm{l}$ on two consecutive readings, were used in the treatment study.

P. obesus were treated with vehicle $(n=5)$ or $1 \mathrm{mg} / \mathrm{kg}$ $(n=8), 3 \mathrm{mg} / \mathrm{kg}(n=11)$ or $10 \mathrm{mg} / \mathrm{kg}(n=7)$ lansoprazole in the first study. At the start of the experiment there were 1012 animals in each group, except for the $10 \mathrm{mg} / \mathrm{kg}$ group, which was smaller due to lack of compound. During the study, five animals in the vehicle group and two in the $1 \mathrm{mg} / \mathrm{kg}$ group had to be killed due to severely elevated $\mathrm{mBG}$ and ketoacidosis. Two animals, one from the $3 \mathrm{mg} / \mathrm{kg}$ group and one from the $10 \mathrm{mg} / \mathrm{kg}$ group, died due to dosing into the lungs. They were removed from all the analyses. The second study consisted of animals dosed with vehicle $(n=8)$ or $10 \mathrm{mg} / \mathrm{kg}(n=8)$ or $15 \mathrm{mg} / \mathrm{kg}(n=8)$ lansoprazole. Both studies were conducted over 2.5 weeks, during which $\mathrm{mBG}, \mathrm{BW}$ and $\mathrm{HbA}_{1 \mathrm{c}}$ were monitored, and gastrin levels were measured at the end of the study. Pancreases from the groups receiving 10 and $15 \mathrm{mg} / \mathrm{kg}$ were evaluated histologically for insulin content and BCM.

The study was approved by the Animal Experiments Inspectorate, Ministry of Justice, Denmark.

Formulation of lansoprazole Lansoprazole (L8533; SigmaAldrich, Broendby, Denmark) was suspended in vehicle $\left(0.6 \%\right.$ carboxymethylcellulose, $\left.0.2 \% \mathrm{NaHCO}_{3}\right)$ to the final dose volume of $2 \mathrm{ml} / \mathrm{kg}$.

$m B G$ and $H b A_{l c}$ Blood samples were collected from the tail, and $\mathrm{mBG}$ and $\mathrm{HbA}_{1 \mathrm{c}}$ measured as previously described [5].

Endogenous gastrin Gastrin levels were measured in samples collected from the aorta using a competition scintillation proximity assay (SPA). Briefly, SPA beads, coated with anti-rabbit antibody, were incubated with rabbit anti-gastrin antibody and ${ }^{125}$ I-labelled Tyr12-gastrin (human). Sample, standard or control was added to the plates, followed by $10 \mu$ l of antibody rabbit-anti-gastrin serum
(\#2609 11/10-73; gift from J. Rehfeld, University Hospital, Copenhagen, Denmark) diluted in assay buffer, $10 \mu \mathrm{l}$ tracer ([ $\left.{ }^{125} \mathrm{I}-T y r^{12}\right]$-gastrin I [human]), $0.37 \mathrm{MBq} / \mathrm{ml}$ NEX176 (Amersham, Cardiff, UK) and $10 \mu \mathrm{l}$ bead solution (AntiRabbit Coupled Polystyrene SPA RPQ0742; GE Healthcare, Umeå, Sweden). The plates were mixed and left for 6$24 \mathrm{~h}$, after which they were centrifuged and counted (LEADseeker; GE Healthcare).

Pancreas histology The pancreases were examined histologically, as previously described [5]. Briefly, pancreases were fixed in paraformaldehyde and sectioned according to the smooth fractionator principle with $F=1 / 4$ of the fragments in each of the two capsules [6]. The sections were stained for insulin to visualise beta cells. BCM was evaluated stereologically in two to three sections with the observer blinded to the origin of the sections. The insulin staining intensity was graded semiquantitatively on a scale of $0-5$, with 0 being equal to islets characterised by absence of insulin staining while 5 equals islets with insulin staining as seen in normal rat pancreas. The grading was carried out with the observer blinded to the origin of the sections.

Statistical analysis Data were analysed using nonparametric (Kruskal-Wallis) ANOVA with Dunn's multiple comparisons as post test or a non-parametric paired $t$ test (Wilcoxon). $p \leq 0.05$ was considered significant. Data are presented as mean \pm SEM.

\section{Results}

Glycaemic control In the first experimental setup, 2.5 weeks of treatment had no significant effects on $\mathrm{mBG}$ in the vehicle and low-dose lansoprazole ( 1 and $3 \mathrm{mg} / \mathrm{kg}$ ) groups. $\mathrm{mBG}$ at end of study was $18.2 \pm 2.1,21.7 \pm 1.5$ and $14.4 \pm$ $2.2 \mathrm{mmol} / 1$ for vehicle $(n=5)$ and lansoprazole $1 \mathrm{mg} / \mathrm{kg}$ $(n=8)$ and $3 \mathrm{mg} / \mathrm{kg}(n=11)$, respectively (Fig. 1a). The animals treated with the highest dose $(10 \mathrm{mg} / \mathrm{kg})$ had significantly lower $\mathrm{mBG}(8.7 \pm 2.2 \mathrm{mmol} / \mathrm{l}, p<0.01)$ at the end of the study. At start of treatment, there were no significant differences in $\mathrm{mBG}$ and $\mathrm{HbA}_{1 \mathrm{c}}$ for the different treatment groups (Fig. 1a, b). At the end of the study period, $\mathrm{HbA}_{1 \mathrm{c}}$ levels in the animals treated with the highest dose $(10 \mathrm{mg} / \mathrm{kg})$ of lansoprazole were significantly lower $(7.7 \pm 0.6 \%)$ than with vehicle $(10.3 \pm 0.5 \%, p<0.05)$ or with $1 \mathrm{mg} / \mathrm{kg}(11.0 \pm 0.5, p<0.05)$ or $3 \mathrm{mg} / \mathrm{kg}$ lansoprazole $(9.5 \pm 0.5 \%, p<0.05$; Fig. $1 b)$.

In a subsequent study, primarily focusing on pancreas histology and a higher dose of lansoprazole, similar results were obtained (Fig. 1c, d). There was no reduction in $\mathrm{mBG}$ 
Fig. 1 Morning blood glucose (BG) $(\mathbf{a}, \mathbf{c})$ and $\mathrm{HbA}_{1 \mathrm{c}}(\mathbf{b}, \mathbf{d})$ in Psammomys obesus before and during treatment with vehicle or different doses of lansoprazole. a, b Black squares, vehicle $(n=5)$; white squares, lansoprazole $1 \mathrm{mg} / \mathrm{kg}(n=8)$; black circles, lansoprazole $3 \mathrm{mg} / \mathrm{kg}$ $(n=11)$; white circles, lansoprazole $10 \mathrm{mg} / \mathrm{kg}(n=7)$. c, d Black squares, vehicle $(n=8)$; white squares, lansoprazole $10 \mathrm{mg} / \mathrm{kg}(n=8)$; black circles, lansoprazole $15 \mathrm{mg} / \mathrm{kg}$ $(n=8)$. HE, high energy. Data are expressed as mean \pm SEM
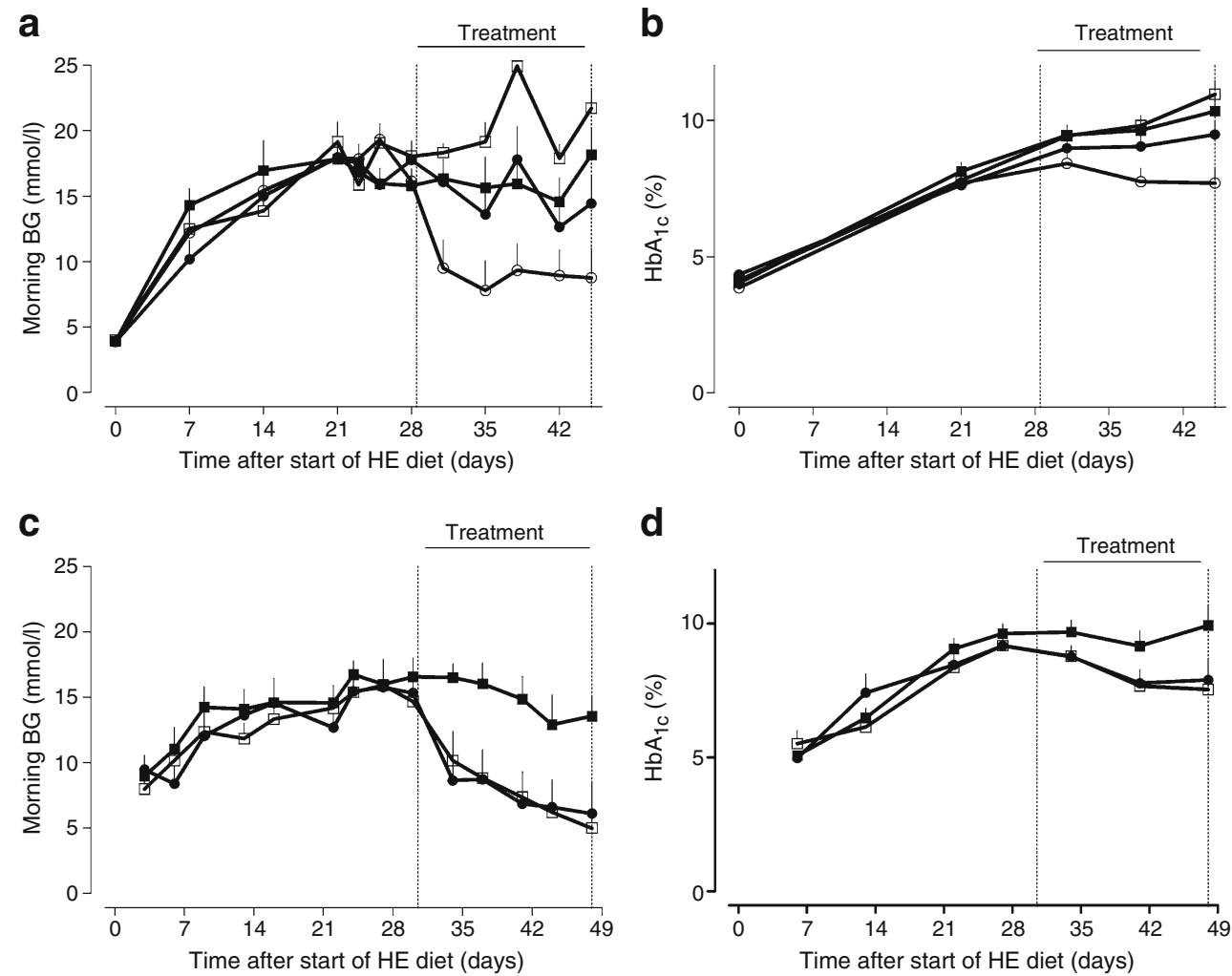

in the vehicle-treated group $(n=8) ; \mathrm{mBG}$ at end of study was $13.6 \pm 1.5 \mathrm{mmol} / \mathrm{l}$. In the lansoprazole $10 \mathrm{mg} / \mathrm{kg}$ group $\mathrm{mBG}$ was significantly reduced to $5.0 \pm 1.4(p<0.001)$ and in the $15 \mathrm{mg} / \mathrm{kg}$ group to $6.1 \pm 2.3 \mathrm{mmol} / \mathrm{l}(p<0.001$ compared with vehicle) (Fig. 1c). Likewise, $\mathrm{HbA}_{1 \mathrm{c}}$ in the animals treated with 10 and $15 \mathrm{mg} / \mathrm{kg}$ of lansoprazole was significantly lower $(6.9 \pm 0.3 \%$ and $7.0 \pm 0.3 \%$ respectively, $p<0.01)$ than in the vehicle-treated animals $(10.4 \pm 0.7 \%$; Fig. 1d).

$B W$ During the study, no difference was observed in BW gain between the groups (data not shown).

Endogenous gastrin After 17 days of treatment with lansoprazole (1, 3 and $10 \mathrm{mg} / \mathrm{kg})$, endogenous gastrin levels were dose-dependently increased by up to ninefold in the animals treated with $10 \mathrm{mg} / \mathrm{kg}$ ( $p<0.05$ vs vehicle, Fig. 2a); no further increase was seen in the $15 \mathrm{mg} / \mathrm{kg}$ group (Fig. 2b).

$B C M$ and intensity of insulin staining Stereological quantification of BCM revealed that the animals treated with 10 and $15 \mathrm{mg} / \mathrm{kg}$ lansoprazole had 40\% (NS) and 50\% ( $p=$ 0.04) higher BCM, respectively, compared with vehicletreated animals (Fig. 2c).

Immunohistochemical analysis of the pancreas showed a 2.3-fold increase in the intensity of the insulin staining in the lansoprazole-treated animals compared with the vehicletreated animals ( $p=0.0002$; Fig. $2 \mathrm{~d})$.

\section{Discussion}

Our results show that the PPI lansoprazole increases endogenous gastrin levels in $P$. obesus, glycaemic control
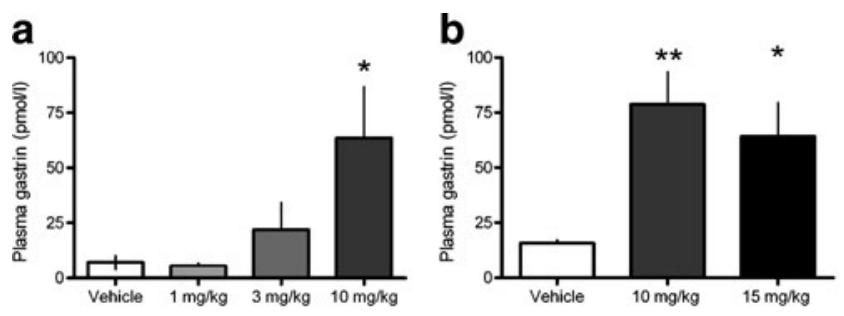

C
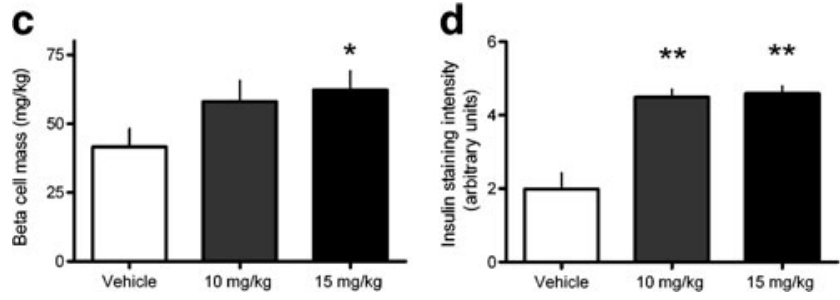

Fig. 2 Plasma gastrin levels (a, b), beta cell mass (c) and intensity of insulin staining in pancreatic sections (d) from Psammomys obesus after 17 days of treatment with vehicle or different doses of lansoprazole. a White bar, vehicle $(n=5)$; very pale grey bar, lansoprazole $1 \mathrm{mg} / \mathrm{kg}$ $(n=8)$; pale grey bar, lansoprazole $3 \mathrm{mg} / \mathrm{kg}(n=11)$; dark grey bar, lansoprazole $10 \mathrm{mg} / \mathrm{kg}(n=7)$. b White bar, vehicle $(n=5)$; dark grey bar, lansoprazole $10 \mathrm{mg} / \mathrm{kg}(n=7)$; black bar, lansoprazole $15 \mathrm{mg} / \mathrm{kg}(n=8)$. c, d White bar, vehicle $(n=5)$; dark grey bar, lansoprazole $10 \mathrm{mg} / \mathrm{kg}(n=$ 7); black bar, lansoprazole $15 \mathrm{mg} / \mathrm{kg}(n=8)$. Data are expressed as mean \pm SEM. ${ }^{*} p<0.05$ vs vehicle-treated animals; $* * p<0.01$ vs vehicletreated animals 
is almost normalised and $\mathrm{BCM}$ and insulin content of the pancreas are increased. Several studies have shown that PPIs elevate gastrin levels in both rodents and humans, and in this study we show this also to be the case in P. obesus. It has been shown that treatment with gastrin alone can induce formation of new beta cells under different conditions $[1,2]$; however, from the present study we cannot determine whether the increased beta cell mass is due to an increase in neogenesis and/or proliferation or a decrease in apoptosis. Further studies that directly address these mechanisms are warranted also in light of the possibility that rodents have a higher capacity for regeneration of BCM than humans.

Although we did not directly measure beta cell function, there was a significant reduction in $\mathrm{mBG}$ and $\mathrm{HbA}_{1 \mathrm{c}}$, which are both clinically relevant variables to measure for any agent that influences beta cell function or BCM.

Even though it is known that PPIs stimulate gastrin production, treatment with PPIs will result in very different pharmacokinetic profiles as compared with gastrin injections. Therefore, it could not be expected that PPIs would have the same effect on expansion of beta cell mass and function as has previously been demonstrated with gastrin. Whereas gastrin, in the doses used in the in vivo rodent studies, has a short half-life in rodents (less than $10 \mathrm{~min}$; T. B. Bödvarsdóttir, L. Pridal, unpublished results), which results in a high exposure for a short time period, PPI treatment, in contrast, will result in a chronic elevation of gastrin levels to a few times above normal. A direct comparison of gastrin and PPIs is needed in order to clarify whether PPI treatment is superior to gastrin or vice versa. But, since PPIs are readily available as oral agents with a long-standing record of safety, the data presented here from lansoprazole-treated $P$. obesus warrant further studies of the clinical benefits of PPIs in type 2 diabetes.

In conclusion, the PPI lansoprazole has significant glucose-lowering effects in an animal model of type 2 diabetes, and thus PPIs might have the potential to become a new class of safe glucose-lowering agents, provided these findings can be extrapolated to other PPIs and humans.

Acknowledgements We thank H. Jensen-Holm, M. Jorgensen, S. Primdahl, P. Rothe and A. Hansen, Novo Nordisk Diabetes \& Obesity Pharmacology, Måløv, Denmark for expert technical assistance and J. Rehfeld, University Hospital, Copenhagen, Denmark for the kind provision of gastrin antibodies.

Duality of interest The authors declare that there is no duality of interest associated with this manuscript.

Open Access This article is distributed under the terms of the Creative Commons Attribution Noncommercial License which permits any noncommercial use, distribution, and reproduction in any medium, provided the original author(s) and source are credited.

\section{References}

1. Suarez-Pinzon WL, Lakey JRT, Brand SJ, Rabinovitch A (2005) Combination therapy with epidermal growth factor and gastrin induces neogenesis of human islet $\beta$-cells from pancreatic duct cells and an increase in functional $\beta$-cell mass. J Clin Endocrinol Metab 90:3401-3409

2. Rooman I, Lardon J, Bouwens L (2002) Gastrin stimulates $\beta$-cell neogenesis and increases islet mass from transdifferentiated but not from normal exocrine pancreas tissue. Diabetes 51:686-690

3. Suarez-Pinzon WL, Cembrowski GS, Rabinovitch A (2009) Combination therapy with a dipeptidyl peptidase-4 inhibitor and a proton pump inhibitor restores normoglycaemia in non-obese diabetic mice. Diabetologia 52:1680-1682

4. Kaiser K, Yuli M, Üçkaya G et al (2005) Dynamic changes in ßcell mass and pancreatic insulin during the evolution of nutritiondependent diabetes in Psammomys obesus: impact of glycemic control. Diabetes 54:138-145

5. Vedtofte L, Bödvarsdóttir TB, Gotfredsen CF, Karlsen AE, Knudsen LB, Heller RS (2010) Liraglutide, but not vildagliptin, restores normoglycaemia and insulin content in the animal model of type 2 diabetes, Psammomys obesus. Regul Pept 160:106-114

6. Gundersen HJG (2002) The smooth fractionator. J Microsc 207:191-210 